\title{
PERTANGGUNGJAWABAN HUKUM BANK ATAS KELALAIAN PEGAWAINYA TERHADAP DEBITUR YANG TERKENA BI CHECKING (Studi Putusan No.15/Pdt.G/2015/PN WNO)
}

\author{
Namira Albabana \\ Fakultas Hukum Universitas Indonesia, Jakarta \\ E-mail: namiraalbabana@gmail.com
}

\begin{abstract}
This study aims to examine the concept of legal liability of banks that commit illegal acts and to analyze the legal liability of banks for their negligence towards debtors affected by BI checking. The research method used is Normative Juridical based on secondary legal materials. This research uses approaches: statute approach, conceptual approach, and case approach. The technique of tracing legal materials uses document study techniques (Research library), and analysis of studies using qualitative analysis. The results showed that the Bank's negligence caused the debtor to be exposed to BI checking, which could harm the debtor and creditor. If we see a causal relationship between an act and a loss if by applying adequate theorie, the Bank is said to have committed an unlawful act that can reasonably be expected to arise. the factors which have an effect, are only considered relevant factors that have the characteristics to cause the effect. With the negligence of the bank, it will cause losses, both material and immaterial losses. Based on Article 1367 the Civil Code uses the theory of vicarious liability. The bank which is where the employees work is charged with absolute liability. Where pursuant to Article 1367 paragraph (1) of the Civil Code determines that a person is not only responsible for losses caused by his own actions, but also for the actions of the person being the dependent or the goods under his supervision. or what is commonly referred to.
\end{abstract}

Keywords: Legal Liability, Bank, Negligence, BI Checking

\begin{abstract}
Abstrak
Penelitian ini bertujuan untuk meneliti konsep pertanggungjawaban hukum Bank yang melakukan perbuatan melawan hukum dan untuk menganalisis pertanggungjawaban hukum bank atas kelalaiannya terhadap debitur yang terkena BI checking. Metode penelitian yang digunakan adalah Yuridis Normatif yang didasarkan pada bahan hukum sekunder. Penelitian ini menggunakan pendekatan: statute approach, conceptual approach, serta case approach. Tehnik penelusuran bahan hukum menggunakan tehnik studi dokumen (library Research), serta analisis kajian menggunakan analisis kualitatif. Hasil penelitian menunjukkan Dengan adanya kelalaian Bank yang mengakibatkan debitur terkena BI checking, dapat merugikan debitur dan kreditur. Bila melihat adanya hubungan kausal antara perbuatan dengan kerugian apabila dengan menerapkan adequate theorie maka Bank dikatakan melakukan perbuatan melawan hukum yang secara layak dapat diperkirakan akan timbul Dalam Pasal 1365 KUHPerdata, dengan jelas, keharusan adanya hubungan kausal yang timbul karena perbuatan melawan hukum dan dari sekian banyak faktor yang sama-sama menimbulkan akibat, maka hanya dianggap relevan faktor yang memiliki ciri untuk menimbulkan akibat tersebut. Dengan adanya kelalaian dari bank maka menimbulkan kerugian, baik kerugian materiil dan immateriil. Berdasarkan Pasal 1367 KUHPerdata
\end{abstract}


menggunakan teori tanggung jawab pengganti atau vicarious liability. Bank yang merupakan tempat pegawainya bekerja dibebankan tanggung jawab mutlak (strict liability). Dimana berdasarkan Pasal 1367 ayat (1) KUHPerdata menentukan bahwa seseorang tidak hanya bertanggung jawab untuk kerugian yang disebabkan karena perbuatannya sendiri, tetapi juga terhadap perbuatan orang yang menjadi tanggungannya atau barang-barang yang berada dalam pengawasannya. atau yang biasa disebut.

Kata Kunci: Pertanggungjawaban Hukum, Bank, Kelalaian, BI Checking

\section{Pendahuluan}

Bank merupakan lembaga intermediasi, artinya kegiatan utamanya adalah menghimpun dana dan kegiatan penyaluran dana kepada masyarakat. Dana yang ditarik dari masyarakat tersebut disalurkan kembali kepada masyarakat. ${ }^{1}$ Fungsi lembaga perbankan sebagai perantara pihak-pihak yang memiliki kelebihan dana dengan pihak- pihak yang memerlukan dana membawa konsekuensi yang intensif antara bank sebagai pelaku usaha dengan nasabah sebagai konsumen pengguna jasa perbankan. Interaksi antara bank dengan konsumen pengguna jasa perbankan yang selanjutnya disebut nasabah dapat pula mengambil bentuk produk lain bank pada saat nasabah melakukan transaksi lain tersebut seperti misalnya jasa transfer dana, maupun deposit.

Pada prinsipnya hubungan antara bank dan nasabah penyimpan dananya dilandasi hubungan kepercayaan, yang lazimnya disebut fiduciary relation. Bank terutama bekerja dengan dana dari masyarakat yang disimpan padanya atas dasar kepercayaan, sehingga setiap bank perlu terus menjaga kesehatannya dengan tetap memelihara dan mempertahankan kepercayaan masyarakat padanya. Bank sangat berkepentingan agar kadar kepercayaan masyarakat yang telah maupun akan menyimpan dananya, terjaga dengan baik dalam tingkat tinggi, mengingat bank adalah bagian dari sistem keuangan dan sistem pembayaran, masyarakat luas berkepentingan atas kesehatan dari sistem- sistem tersebut. Sedangkan kepercayaan masyarakat kepada bank merupakan unsur pokok dari eksistensi suatu bank, maka terjaganya kepercayaan masyarakat kepada perbankan adalah juga kepentingan masyarakat banyak. ${ }^{2}$

Bank dalam melakukan kegiatan usahanya wajib menerapkan prinsip kehatihatian, dan juga harus menjaga kesehatan bank agar tetap terjaga terus demi kepentingan masyarakat pada umumnya dan bagi para nasabah penyimpan dana. Sebagai lembaga keuangan, bank yang merupakan tempat masyarakat menyimpan dananya dilandasi oleh kepercayaan bahwa uangnya akan dapat diperoleh kembali pada waktunya dan disertai bunga dimana yang dimaksud adalah bahwa suatu bank sangat tergantung pada kepercayaan masyarakat tersebut.

Semakin tinggi kepercayaan masyarakat kepada bank, semakin tinggi pula kesadaran masyarakat untuk menyimpan uangnya di bank dan menggunakan jasa-jasa lainnya dari bank. Bank- bank dalam memberikan produk- produk yang ditawarkan, berusaha semaksimal mungkin untuk menarik simpati masyarakat. Sedangkan bagi

${ }^{1}$ Ronny Prasetya, Pembobolan ATM, Tinjauan Hukum Perlindungan Nasabah, Lex Crimen, Vol.II/No.1/Jan-Mrt/2013.

${ }^{2}$ Mauritz Pray Takasenseran, Perjanjian Antara Bank dengan Nasabah Menurut Undang-Undang Nomor 10 Tahun 1998, Lex et Societatis, Vol.IV/No.7/Juli 2016. 
para nasabah harus memahami benar bank yang bagaimana yang dapat dipercaya,nasabah jangan hanya tergiur oleh bunga yang tinggi maupun bonus atau hadiah dan lainnya, jika ternyata bank yang dipercaya tersebut memiliki kondisi yang kurang baik.

Ada beberapa faktor yang mempengaruhi tingkat kepercayaan masyarakat terhadap suatu bank. Faktor- faktor tersebut yaitu integritas pengurus, pengetahuan dan kemampuan pengurus baik berupa pengetahuan kemampuan manajerial maupun pengetahuan dan kemampuan teknis perbankan, kesehatan bank yang bersangkutan, dan kepatuhan bank terhadap kewajiban bank. ${ }^{3}$

Nasabah merupakan konsumen bank dalam haknya mendapatkan informasi tentang dananya dari pelayanan jasa perbankan. Pihak nasabah merupakan unsur yang sangat berperan sekali, eksistensi perbankan bersandar kepada kepercayaan dari pihak masyarakat atau nasabah. Sesungguhnya hubungan antara bank dan nasabah bukan sekedar hubungan kontraktual biasa antara bank dan nasabah yang diliputi oleh asasasas umum` dari hukum perjanjian, tetapi juga hubungan kepercayaan yang diliputi asas kepercayaan.

Salah satu kegiatan khusus yang dijalankan bank umum adalah memberikan kredit. Pemberian kredit oleh bank merupakan salah satu bentuk fungsi bank, yaitu sebagai penyalur dana dari masyarakat. Bank dalam memberikan kredit kepada nasabah didasarkan atas kepercayaan, oleh karena itu untuk menjaga keamanannya sudah seharusnya bank di dalam menyalurkan kredit benar- benar yakin bahwa nasabahnya akan mampu mengembalikan pinjaman yang diterimanya dengan waktu yang telah dijanjikan. ${ }^{4}$ Sejalan dengan apa yang diatur dalam pasal 2 Undang- Undang Nomor 10 Tahun 1998 tentang Perubahan Atas Undang- Undang Nomor 7 Tahun 1992 Tentang Perbankan yang menyebutkan bahwa perbankan Indonesia dalam melakukan usahanya berdasarkan demokrasi ekonomi dengan menggunakan prinsip kehati-hatian. Adapun rangkaian dari prinsip kehati- hatian adalah Prinsip Mengenal Nasabah dan Sistem Informasi Debitur.

Salah satu faktor penyebab gagalnya aplikasi pinjaman permodalan di bank atau lembaga keuangan lain adalah status nasabah di dalam Sistem Informasi Debitur (SID) milik Bank Indonesia (BI). Bank Indonesia memiliki daftar hitam yang dibuat untuk memuat nama nasabah debitur, baik individu maupun perusahaan yang terkena sanksi karena telah melakukan tindakan tertentu yang merugikan bank dan masyarakat. Sebagai contoh tidak kembalinya dana kredit atau dapat dikatakan sebagai kredit macet, maka nasabah debitur secara otomatis akan tercatat dalam daftar Sistem Informasi Debitur (SID) yaitu sistem yang menyediakan informasi debitur yang merupakan hasil olahan dari laporan debitur yang dibuat oleh bank atau lembaga keuangan yang menjadi anggota Sistem Informasi Debitur (SID) berdasarkan Peraturan Bank Indonesia (PBI) Nomor 9/14/2007 tentang Sistem Informasi Debitur.

Hal ini dapat menimbulkan gugatan perbuatan melawan hukum dalam perjanjian kredit. Perbuatan melawan hukum (Onrechtmatigedaad) ${ }^{5}$ sendiri diatur dalam

\footnotetext{
${ }^{3}$ Rani Sri Agustina, Rahasia Bank, Keni Medi, 2017, Hlm. 3.

${ }^{4}$ Selamat Widodo, Tanggung Jawab Perdata Bank Terhadap Tindakan Fraud Karyawan Yang Merugikan Nasabah, Kosmik Hukum, Vol 14, No 2 (2014), DOI: 10.30595/kosmikhukum.v14i2.742

${ }^{5}$ Dalam menerjemahkan Onrechtmatigedaad tersebut, belum dapat menemukan istilah dalam bahasa Indonesia yang sebenarnya dan masih terdapat kemungkinan terjemahan lainnya, yakni "perbuatan
} 
buku III KUHPerdata mulai dari pasal 1365 sampai dengan pasal 1380. Onrechtmatigedaad mengatur syarat-syarat untuk menuntut ganti kerugian karena perbuatan melawan hukum. Pasal 1365 KUHPerdata tidaklah memberikan perumusan, melainkan hanya mengatur seseorang yang mengalami kerugian karena perbuatan melawan hukum, yang dilakukan oleh orang lain terhadap dirinya, dapat mengajukan tuntutan ganti kerugian pada Pengadilan Negeri dengan sukses. ${ }^{6}$

Salah satu kasus gugatan perbuatan melawan hukum dalam hal kelalain Bank yang diajukan oleh nasabah ke pengadilan seperti pada Putusan No.15/Pdt.G/2015/PN Wno., dimana Bank dinyatakan bersalah dengan Perbuatan Melawan hukum akibat kelalaian yang mengakibatkan penggugat terkena BI checking, dan menghukum Bank untuk mengembalikan kondisi Penggugat kepada semula dengan melakukan koreksi terhadap SID yang telah dilaporkan kepada Bank Indonesia, paling lambat 1 (satu) hari setelah putusan perkara ini berkekuatan hukum tetap.

Berdasarkan uraian diatas, maka penelitian ini bertujuan untuk meneliti konsep pertanggungjawaban hukum Bank yang melakukan perbuatan melawan hukum dan untuk menganalisis pertanggungjawaban hukum bank atas kelalaiannya terhadap debitur yang terkena BI checking.

\section{Metode Penelitian}

Metode penelitian yang digunakan adalah Yuridis Normatif, yaitu penelitian yang menggunakan data diperoleh melalui bahan kepustakaan? ${ }^{7}$. Langkah pertama yang dilakukan penelitian ini didasarkan pada bahan hukum sekunder yaitu mencakup dokumen perundang-undangan, dokumen resmi, buku-buku, yurisprudensi yang berkaitan dengan analisa hukum perdata khususnya terhadap asas dan peraturan mengenai tanggung jawab bank sebagai badan hukum atas perbuatan melawan hukum bank terhadap debitur yang terkena BI checking. Penelitian ini menggunakan pendekatan: statute approach, conceptual approach, serta case approach. Tehnik penelusuran bahan hukum menggunakan tehnik studi dokumen (library Research), serta analisis kajian menggunakan analisis kualitatif.

\section{Hasil Dan Pembahasan}

\subsection{Konsep Pertanggungjawaban Hukum Bank Yang Melakukan Perbuatan Melawan Hukum}

Indonesia menganut sistem Civil Law dan sistem hukum Eropa Kontinental, ${ }^{8}$ yaitu sistem yang berpatokan pada undang-undang, yang dalam beberapa bidang hukum sering kali berupa seperangkat peraturan yang dikodifikasikan dan dikumpulkan dalam satu kitab perundang-undangan. Dalam konteks

menyalahi hukum" atau "perbuatan bertentangan hukum". Selanjutnya lihat Hermansyah, Hukum Perbankan Nasional Indonesia, cet.6, Jakarta, Kencana Prenada Media Group, 2011, Hlm. 12.

${ }^{6}$ Anggita Maynanda Pratiwi, Perlindungan Hukum Terhadap Nasabah Debitur yang Terlapor Dalam Sistem Informasi, Diponegoro Law Review, Vol. 5 No. 2, 2016.

${ }^{7}$ Zainuddin Ali, Metode Penelitian Hukum, Jakarta, Sinar Grafika, 2016, Hlm. 22.

${ }^{8}$ H.R Sardjono dan Frieda Husni Hasbullah, Bunga Rampai Perbandingan Hukum Perdata, Cet. Kedua IND-HILL-CO, 2003, Hlm. 59. 
pertanggungjawaban perdata, ini berarti bahwa secara umum pertanggungjawaban berdasarkan Perbuatan Melawan Hukum selalu mengacu pada Pasal 1365 KUH Perdata. Dalam hal ini, untuk dikatakan sebagai Perbuatan Melawan Hukum sebuah perbuatan haruslah terbukti melawan hukum, dan harus pula terbukti adanya kerugian yang ditimbulkan akibat perbuatan tersebut. Macam-macam tanggung jawab adalah sebagai berikut: ${ }^{9}$

1. Tanggung jawab dan Individu

Pada hakikatnya hanya masing-masing individu yang dapat bertanggungjawab. Hanya mereka yang memikul akibat dari perbuatan mereka. Oleh karenanya, istilah tanggungjawab pribadi atau tanggungjawab sendiri sebenarnya "mubazir". Suatu masyarakat yang tidak mengakui bahwa setiap individu mempunyai nilainya sendiri yang berhak diikutinya tidak mampu menghargai martabat individu tersebut dan tidak mampu mengenali hakikat kebebasan.

\section{Tanggung jawab dan kebebasan}

Kebebasan dan tanggungjawab tidak dapat dipisahkan. Orang yang dapat bertanggung jawab terhadap tindakannya dan mempertanggungjawabkan perbuatannya hanyalah orang yang mengambil keputusan dan bertindak tanpa tekanan dari pihak manapun atau secara bebas. Liberalisme menghendaki satu bentuk kehidupan bersama yang memungkinkan manusianya untuk membuat keputusan sendiri tentang hidup mereka. Karena itu bagi suatu masyarakat liberal hal yang mendasar adalah bahwa setiap individu harus mengambilalih tanggungjawab. Ini merupakan kebalikan dari konsep sosialis yang mendelegasikan tanggungjawab dalam ukuran seperlunya kepada masyarakat atau negara. Kebebasan berarti tanggungjawab; Itulah sebabnya mengapa kebanyakan manusia takut terhadapnya.

\section{Tanggungjawab sosial}

Dalam diskusi politik sering disebut-sebut istilah tanggungjawab sosial. Istilah ini dianggap sebagai bentuk khusus, lebih tinggi dari tanggungjawab secara umum. Namun berbeda dari penggunaan bahasa yang ada, tanggungjawab sosial dan solidaritas muncul dari tanggungjawab pribadi dan sekaligus menuntut kebebasan dan persaingan dalam ukuran yang tinggi.

Untuk mengimbangi tanggungjawab sosial tersebut pemerintah membuat sejumlah sistem, mulai dari Lembaga Federal untuk Pekerjaan sampai asuransi dana pensiun yang dibiayai dengan uang pajak atau sumbangan-sumbangan paksaan. Institusi yang terkait ditentukan dengan keanggotaan paksaan. Karena itu institusi-institusi tersebut tidak mempunyai kualitas moral organisasi yang bersifat sukarela. Orang yang terlibat dalam organisasi-organisasi seperti ini adalah mereka yang melaksanakan tanggungjawab pribadi untuk diri sendiri dan orang lain. Semboyan umum semua birokrat adalah perlindungan sebagai ganti

\footnotetext{
${ }^{9}$ Widiyono, Wewenang Dan Tanggung Jawab, Jakarta, Ghalia Indonesia, 2004, Hlm. 27.
} 
tanggungjawab. ${ }^{10}$

4. Tanggung jawab terhadap orang lain

Setiap manusia mempunyai kemungkinan dan di banyak situasi juga kewajiban moral atau hukum untuk bertanggungjawab terhadap orang lain. Secara tradisional keluarga adalah tempat dimana manusia saling memberikan tanggung jawabnya. Si orang tua bertanggungjawab kepada anaknya, anggota keluarga saling tanggungjawab. Tanggungjawab terhadap orang lain seperti ini tentu saja dapat diterapkan di luar lingkungan keluarga. Bentuknya bisa banyak hal dan yang penting adalah prinsip sukarela - pada kedua belah pihak. Pertanggungjawaban manusia terhadap dirinya sendiri tidak boleh digantikan dengan perwalian.

5. Tanggungjawab dan Risiko

Dalam masyarakat modern orang berhadapan dengan berbagai risiko. Risiko itu bisa membuat orang sakit dan membutuhkan penanganan medis yang sangat mahal. Atau membuat orang kehilangan pekerjaan dan bahkan harta bendanya. Ada berbagai cara untuk mengamankan dari risiko tersebut, misalnya dengan asuransi. Untuk itu tidak diperlukan organisasi pemerintah, melainkan hanya tindakan setiap individu yang penuh tanggung jawab dan bijaksana.

Di samping berdasarkan Perbuatan Melawan Hukum, sistem hukum Indonesia juga mengenal adanya pertanggungjawaban mutlak (strictliability). Sistem pertanggungjawaban ini ditujukan khusus untuk kerugian akibat dari perbuatanperbuatan tertentu yang dianggap berbahaya atau berisiko tinggi.

Selain orang-orang (manusia), di dalam hukum juga ditentukan bahwa perkumpulan-perkumpulan dan badan-badan dapat juga memiliki hak-hak dan melakukan perbuatan-perbuatan hukum seperti seorang manusia. ${ }^{11}$ Badan-badan dan perkumpulan itu mempunyai kekayaan sendiri, ikut serta dalam lalu lintas hukum dengan perantara pengurusnya, dapat digugat dan dapat juga menggugat di muka Hakim. ${ }^{12}$ Menurut Prof. Wirjono Prodjodikoro, badan hukum adalah suatu badan yang di samping manusia perorangan juga dianggap dapat bertindak dalam hukum dan juga mempunyai hak-hak, kewajiban-kewajiban dan perhubungan hukum terhadap orang atau badan lain.

Teori badan hukum bank yang menjadi pedoman penulisan ini adalah Teori Organ yaitu teori yang mengakui adanya orang di samping para anggotanya, tapi bukanlah orang yang dibayangkan, melainkan merupakan orang sungguh-sungguh, yang mempunyai kecakapan untuk bertindak dan juga kehendaknya sendiri. Kehendak tersebut dibentuk dalam pikiran para organ, akan tetapi karena para anggota tersebut pada waktu membentuk dan mengutarakan kehendaknya bertindak selaku organ., yakni sebagai bagian daripada organisme yang berwujud orang, maka kehendak

${ }^{10}$ Andi Nova Bukit, Pertanggungjawaban Bank Terhadap Hak Nasabah Yang Dirugikan Dalam Pembobolan Rekening Nasabah (Studi Di Pt. Bank Rakyat Indonesia Tbk, Kantor Cabang Medan Gatot Subroto), Jurnal Ius Constituendum, Volume 4 Nomor 2 Oktober 2019.

11 Latumena, Pieter E, Reposisi Pemberian Kuasa dalam Konsep Volmacht dan Lastgeving Berdasarkan Cita Hukum Pancasila, Jurnal Hukum dan Pembangunan 47 (September 2016 - Maret 2017)

12 Ibid., 
tersebut juga merupakan kehendak dari badan hukum. ${ }^{13}$

Mengenai bentuk usaha bank, Undang-Undang Nomor 10 tahun 2008 tentang Perbankan mewajibkan bentuk usaha yang berbadan hukum. Badan hukum dalam bahasa Belanda Rechtspersoon ialah suatu badan yang dapat mempunyai harta kekayaan, hak serta kewajiban seperti orang-orang pribadi". ${ }^{14}$ Sebagai badan hukum memiliki syarat-syarat sebagai berikut: 1) adanya harta kekayaan (hak-hak) dengan tujuan tertentu yang terpisah dengan kekayaan pribadi para sekutu atau Pendiri badan itu, tegasnya ada pemisahan kekayaan perusahaan dengan kekayaan pribadi para sekutu; dan 2) kepentingan yang menjadi tujuan adalah kepentingan bersama; adanya beberapa orang sebagai Pengurus. ${ }^{15}$

Dengan demikian letak perbedaan antara persekutuan perseorangan dengan badan hukum ada pada modal dan letak tanggung jawabnya. Pada usaha perseorangan modal usahanya menjadi satu dengan modal Pendirinya, sehingga tanggung jawabnya termasuk harta kekayaan pribadi Pendiri. Pada perusahaan berbadan hukum, modal usahanya terpisah dari kekayaan para Pendiri (pemegang saham), oleh karenanya tanggungjawab para Pendiri (pemegang saham) sebatas jumlah maksimal modal yang disetorkan. Kekayaan badan hukum tersebut diurus oleh para Pengurusnya sebagai salah satu organ dari badan hukum yang bersangkutan. Berdasarkan uraian ini, maka dapat diketahui Bank sebagai lembaga pembiayaan dapat dikenai pertanggungjawaban hukum.

\subsection{Pertanggungjawaban Hukum Bank atas Kelalaiannya terhadap Debitur yang terkena BI Checking.}

Pengaturan mengenai perbankan ada didalam Undang-Undang No.10 tahun 2008 tentangPerbankan. Menurut Pasal 1 ayat 2, "bank adalah badan usaha yang menghimpun dana darimasyarakat dalam bentuk simpanan dan menyalurkan kepada masyarakat dalam bentuk kredit dan atau bentuk-bentuk lainnya dalam rangka meningkatkan taraf hidup orang banyak."

Mengenai bentuk usaha bank, Undang-Undang No.10 tahun 2008 tentang Perbankan mewajibkan bentuk usaha yang berbadan hukum. Badan hukum dalam bahasa Belanda Rechtspersoon ialah suatu badan yang dapat mempunyai harta kekayaan, hak serta kewajiban seperti orang-orang pribadi". ${ }^{16}$ Sebagai badan hukum memiliki syarat-syarat sebagai berikut:

1. adanya harta kekayaan (hak-hak) dengan tujuan tertentu yang terpisah dengan kekayaan pribadi para sekutu atau Pendiri badan itu, tegasnya ada pemisahan kekayaan perusahaan dengan kekayaan pribadi para sekutu;

2. kepentingan yang menjadi tujuan adalah kepentingan bersama;

${ }^{13}$ Rini Dameria, Achmad Busro, Dewi Hendrawati, Perbuatan Melawan Hukum Dalam Tindakan Medis Dan Penyelesaiannya Di Mahkamah Agung (Studi Kasus Perkara Putusan Mahkamah Agung Nomor 352/Pk/Pdt/2010), Diponegoro Law Journal, Volume 6, Nomor 1, Tahun 2017.

${ }^{14}$ Achmad Busro, Hukum Perikatan Berdasar Buku III KUH Perdata, Percetakan Pohon Cahaya, 2012, Hlm. 7.

${ }^{15}$ Ibid., Hlm 10.

${ }^{16}$ Moh. Zainol Arief dan Sutrisni, Perbuatan Melawan Hukum Dalam Transaksi Jual-Beli Melalui Internet Ditinjau Dari Buku III KUHPerdata", Jurnal Jendela Hukum, Fakultas Hukum Unija, Volume I Nomor 2 September, 2014. 
3. adanya beberapa orang sebagai Pengurus. ${ }^{17}$

Dengan demikian letak perbedaan antara persekutuan perseorangan dengan badan hukum ada pada modal dan letak tanggung jawabnya. Pada usaha perseorangan modal usahanya menjadi satu dengan modal Pendirinya, sehingga tanggung jawabnya termasuk harta kekayaan pribadi Pendiri. Pada perusahaan berbadan hukum, modal usahanya terpisah dari kekayaan para Pendiri (pemegang saham), oleh karenanya tanggungjawab para Pendiri (pemegang saham) sebatas jumlah maksimal modal yang disetorkan. Kekayaan badan hukum tersebut diurus oleh para Pengurusnya sebagai salah satu organ dari badan hukum yang bersangkutan.

Berdasarkan uraian diatas, maka dapat diketahui Bank sebagai lembaga pembiayaan dapat dikenai pertanggungjawaban hukum. Selanjutnya akan dibahas pertanggungjawaban hukum Bank atas kelalaiannya terhadap debitur yang terkena BI checking.

Bank atas kelalaiannyaterhadap debitur yang terkena BI checking, menimbulkan kerugian baik materiil maupun immateriil. Di Indonesia, pertanggungjawaban perdata yang mensyaratkan adanya unsur kesalahan adalah pertanggungjawaban berdasarkan Perbuatan Melawan Hukum. Hal ini dapat dilihat di dalam pasal 1365 KUH Perdata, yaitu bahwa "Tiap perbuatan melanggar hukum, yang membawa kerugian kepada orang lain, mewajibkan orang karena salahnya menerbitkan kerugian itu, mengganti kerugian tersebut."18

Pertanggungjawaban perdata untuk pada umumnya didasarkan pada pertanggungjawaban berdasarkan Perbuatan Melawan Hukum, yang menimbulkan kerugian kepada orang lain...". ${ }^{19}$ Hal senada juga diutarakan oleh N.H.T. Siahaan yang menyatakan bahwa dikaitkan dengan Pasal 1365 KUH Perdata sebagai bentuk pertanggungjawaban atas perbuatan melawan hukum (onrechtsmatigedaad)". Lebih jauh lagi, N.H.T. Siahaan juga menyatakan bahwa Perbuatan Melawan Hukum sebenarnya mengacu pada konsepsi pertanggungjawaban yang konvensional, yaitu pertanggungjawaban yang "didasarkan pada adanya kesalahan (liability based on fault, schuld aansprakelijkheid). Tanpa adanya kesalahan, maka tidak akan timbul dasar untuk menuntut kerugian." 20

Secara umum, untuk dapat mengatakan bahwa seseorang telah melakukan Perbuatan Melawan Hukum, penggugat harus dapat menunjukkan telah terpenuhinya/terbuktinya syarat-syarat berikut:21

1. Perbuatan Melawan Hukum

Perbuatan Melawan Hukum terjadi tidak hanya ketika terjadi pelanggaran hukum tertulis yaitu undang-undang, tetapi juga melanggar hukum tidak tertulis berupa kepatutan, ketelitian atau kehati- hatian. Dalam hal ini, melawan

\footnotetext{
${ }^{17}$ Ibid., Hlm 10.

${ }^{18}$ Subekti Dan R. Tjitrosubidio, Kitab Undang-Undang Hukum Perdata, Pradnya Paramita, 2008, Hlm. 346.

${ }^{19}$ Rivo Krisna Winastri, Ery Agus Priyono, Dewi Hendrawati, Tinjauan Normatif Terhadap Ganti Rugi Dalam Perkara Perbuatan Melawan Hukum Yang Menimbulkan Kerugian Immateriil (Studi Kasus Putusan Pengadilan Negeri Istimewa Jakarta No. 568/1968.G), Diponegoro Law Review, 2017.

${ }^{20}$ N.H.T. Siahaan, Hukum Lingkungan dan Ekologi Pembangunan, Jakarta, Penerbit Erlangga, 2004, Hlm. 310-311.

${ }^{21}$ Rosa Agustina, Perbuatan Melawan Hukum, Hlm. 50.
} 
hukum dianggap sebagai perbuatan yang bertentangan dengan hak orang lain, atau bertentangan dengan kewajiban hukumnya sendiri, atau bertentangan dengan kesusilaan, dan juga bertentangan dengan kehati-hatian atau keharusan dalam pergaulan masyarakat yang baik.

2. Adanya Kesalahan

Unsur kesalahan mencakup kealpaan yaitu kesalahan dalam arti luas dan kesalahan dalam arti sempit. Kesalahan dalam arti luas diwujudkan dalam bentuk tidak melakukan sesuatu, atau telah melakukan sesuatu, secara lain daripada yang seharusnya dilakukan oleh orang-orang umumnya dalam keadaan yang sama. Dalam arti sempit, kesalahan berarti kesengajaan yaitu apabila pelaku tahu betul bahwa perbuatannya akan mengakibatkan kerugian pada pihak lain. Selain itu, unsur kesalahan juga terdiri dari dua pengertian, pertama pengertian yang obyektif yaitu suatu ukuran tingkah laku yang ditentukan menurut ukuran yang umum untuk mencegah terjadinya kerugian. Kedua, pengertian subyektif, yaitu berkenaan dengan pelaku itu sendiri, apakah mempunyai suatu kecakapan untuk mengatasi kerugian yang mungkin timbul, hal ini akan yang akan menentukan apakah bertanggung jawab atas kerugian yang ditimbulkan.

\section{Adanya Kerugian}

Pada dasarnya, kerugian terbagi ke dalam dua bentuk, yaitu kerugian materiil dan kerugian immateriil. Kerugian materiil adalah kerugian yang ditimbulkan oleh pihak lain dan dapat diminta sejumlah nilai untuk ganti rugi tersebut. Sedangkan kerugian immateriil adalah kerugian yang tidak dapat dinilai dengan sejumlah pembayaran tapi menimbulkan rasa tidak tenang, rasa malu, seperti penghinaan dan pencemaran nama baik. Dimungkinkannya ganti kerugian untuk kerugian immateriil bertujuan sebagai upaya mengembalikan keadaan seperti semula, yaitu keadaan sebelum perbuatan melawan hukum terjadi.

4. Ada Hubungan Sebab Akibat (kausalitas)

Diperlukan hubungan sebab akibat untuk mengetahui bagaimanakah hubungan suatu peristiwa yang menimbulkan kerugian pada pihak lain. Dalam hal ini ada di Indonesia dikenal adanya dua bentuk teori kausalitas seperti yang telah dijelaskan sebelumnya.

Hal ini berbeda dengan teori Pertanggungjawaban Mutlak (Strict liability). Lahirnya pertanggungjawaban mutlak atau Strict Liability berawal dari kasus Rylands vs. Fletcher ${ }^{22}$ memenuhi unsur kesalahan (fault). Di Indonesia, Strict Liability pertama kali diadopsi dalam Undang- Undang lingkungan hidup melalui Undang-Undang No. 4

22 Kasus Ryland vs Flectcher adalah sengketa antara penggugat, yakni kegiatan usaha penambangan batu bara di bawah tanah yang lokasi pertambangannya berdekatan dengan tanah tergugat yang digunakan untuk membangun sebuah waduk guna menyuplai air bagi kegiatan mesin penggilingan, Pembangunan waduk ini dilakukan oleh insinyur dan kontraktor yang memiliki keahlian, kegiatan penggalian tanah ini oleh kontraktor dilakukan sampai batas tanah bagian bawah, tergugat dan kontraktor keduanya tidak menyadari bahwa batas tanah tersebut adalah bekas kawasan tambang yang sedang dikerjakan oleh penggugat, setelah waduk selesai dikerjakan dan diisi air, beberapa lama kemudian waduk tersebut jebol dan menggenangi kawasan tambang milik penggugat. Selanjutnya lihat N.H.T. Siahaan, Hukum Lingkungan dan Ekologi Pembangunan (Jakarta: Penerbit Erlangga, 2004), Hlm. 313. 
tahun 1982. Pasal 21 dari undang-undang ini menyatakan bahwa "dalam beberapa kegiatan yang menyangkut jenis sumber daya tertentu tanggung jawab timbul secara mutlak pada perusak dan atau pencemar pada saat terjadinya perusakan dan atau pencemaran lingkungan hidup yang pengaturannya diatur dalam peraturan perundang-undangan yang bersangkutan."

Tanggung jawab tanpa kesalahan atau yang sering disebut tanggung jawab mutlak adalah suatu tanggung jawab hukum yang dibebankan kepada pelaku perbuatan melawan hukum tanpa melihat apakah yang bersangkutan dalam melakukan perbuatannya itu mempunyai unsur kesalahan ataupun tidak, dalam hal ini pelakunya dapat dimintakan tanggung jawab secara hukum, meskipun dalam melakukan perbuatannya itu dia tidak melakukannya dengan sengaja dan tidak pula mengandung unsur kelalaian, kuranghati-hatian, atau ketidakpatutan. Pertanggungjawaban dalam perbuatan melawan hukum salah satunya dirumuskan dalam Pasal 1367 ayat (1) KUHPerdata yang menentukan bahwa seseorang tidak hanya bertanggung jawab untuk kerugian yang disebabkan karena perbuatannya sendiri, tetapi juga terhadap perbuatan orang yang menjadi tanggungannya atau barang-barang yang berada dalam pengawasannya. ${ }^{23}$

Pertanggungjawaban ini dikenal sebagai tanggung gugat atau yang dalam istilah Belanda disebut sebagai aanprakelijkheid yaitu teori yang menentukan siapakah yang harus menerima gugatan atau siapa yang harus digugat karena adanya suatu perbuatan melawan hukum. Terhadap tanggung gugat atas perbuatan melawan hukum yang dilakukan oleh orang lain ini dalam ilmu hukum dikenal dengan teori tanggung jawab pengganti atau vicarious liability. ${ }^{24}$

Putusan Pengadilan dalam kasus pada Putusan No.15/Pdt.G/2015/PNWno. Telah tepat dengan membebankanpertanggungjawaban hukum kepada Bank. Mengenai hal perbuatan melawan hukum yang dilakukan oleh Bank, Pengadilan merumuskan perbuatan melawan hukum Bank didasarkan pada kewajiban untuk melaksanakan kewajiban dalam Sistem Informasi Debitur.

Bank merupakan tempat Pegawai Bank yang bertanggungjawab dalam sistem informasi debitur bekerja dimana berdasarkan Pasal 1367 ayat (1) KUHPerdata menentukan bahwa seseorang tidak hanya bertanggung jawab untuk kerugian yang disebabkan karena perbuatannya sendiri, tetapi juga terhadap perbuatan orang yang menjadi tanggungannya atau barang-barang yang berada dalam pengawasannya. atau yang biasa disebut tanggung jawab pengganti atau vicarious liability. ${ }^{25}$

Vicarious liability merupakan salah bentuk pertanggungjawaban hukum mutlak (strict liability), adalah suatu tanggung jawab hukum yang dibebankan kepada pelaku perbuatan melawan hukum tanpa melihat apakah yang bersangkutan dalam melakukan perbuatannya itu mempunyai unsur kesalahan ataupun tidak, dalam hal ini pelakunya dapat dimintakan tanggung jawab secara hukum, meskipun dalam melakukan perbuatannya itu dia tidak melakukannya dengan sengaja dan tidak pula mengandung unsur kelalaian, kurang kehati-hatian, atau ketidakpatutan. ${ }^{26}$

\footnotetext{
${ }^{23} \mathrm{Ibid} ., \mathrm{Hlm} .171$.

${ }^{24}$ Munir Fuady., Perbuatan Melawan Hukum, Hlm. 17.

${ }^{25}$ Purwosutjipto, Pengertian Pokok Hukum Dagang Indonesia, Jakarta, Djambatan, 2003, Hlm. 171.

${ }^{26}$ Badrulzaman, Mariam Darus, et.al., Kompilasi Hukum Perikatan, PT Citra Aditya Bakti, Bandung, 2011, Hlm. 173.
} 
Pertanggungjawaban dalam perbuatan melawan hukum salah satunya dirumuskan dalam Pasal 1367 ayat (1) KUHPerdata yang menentukan bahwa seseorang tidak hanya bertanggung jawab untuk kerugian yang disebabkan karena perbuatannya sendiri, tetapi juga terhadap perbuatan orang yang menjadi tanggungannya atau barang-barang yang berada dalam pengawasannya. ${ }^{27}$

Salah satu bentuk dari vicarious liability ini adalah teori tanggung jawab atasan (Respondeat Superiora superior risk bearing theory) dimana dalam Pasal 1367 KUHPerdata juga disebutkan beberapa pihak yang harus menerima tanggung gugat dari perbuatan melawan hukum yang dilakukan oleh pihak lain, salah satunya adalah tanggung jawab majikan atas tindakan yang dilakukan oleh pekerjanya ${ }^{28}$ dengan bunyi Pasal sebagai berikut: "Seorang tidak saja bertanggung jawab untuk kerugian yang disebabkan perbuatannya sendiri, tetapi juga untuk kerugian yang disebabkan perbuatan orangorang yang menjadi tanggungannya atau disebabkan oleh barang-barang yang berada dibawah pengawasannya...", dan“...Majikan-majikan dan mereka yang mengangkat orang-orang lain untuk mewakili urusan-urusan mereka, adalah bertanggung jawab tentang kerugian yang diterbitkan oleh pelayan-pelayan atau bawahan-bawahan mereka didalam melakukan pekerjaan untuk mana orang-orang ini dipakainya..." 29

Dalam Pasal 1367 ayat (3), menurut Moegni Djojodirdjo, terdapat beberapa hal yang mengakibatkan adanya tanggung jawab majikan ini, yaitu adanya perjanjian kerja dan tidak adanya ikatan kerja namun adanya penyerahan pekerjaan dari orang yang memimpin sendiri pekerjaannya. ${ }^{30}$ Adanya hubungan majikan dengan bawahan dalam badan hukum dengan organnya ini juga tidak terlepas dari adanya ikatan kerja yang terdapat pada Pasal 1601 a yang menentukan: "Persetujuan perburuhan adalah dengan mana pihak yang satu, si buruh, mengikatkan dirinya untuk di bawah perintahnya pihak yang lain, si majikan, untuk sesuatu waktu tertentu melakukan pekerjaan dengan menerima upah." Sehingga adanya hubungan pekerjaan berdasarkan perjanjian kerja menyebabkan seorang menjadi majikan dan seorang menjadi bawahan.

Adanya pertanggungjawaban berdasarkan pasal 1367 KUHPerdata adalah hanya kerugian yang timbul saat bawahan menjalankan pekerjaannya yang sesuai dengan tujuan bawahan tersebut dipekerjakan. Selain itu, dapat juga dikenakan tanggung jawab apabila perbuatan bawahan tersebut walaupun tidak sesuai dengan pekerjaan yang dilakukan tetapi setidaknya masih terdapat hubungan dengan pekerjaan yang dilakukannya. Hal ini terlihat pada putusan Hoge Raad tanggal 4 November 1938, yaitu: "Pertanggungjawaban berdasarkan Pasal 1367 KUHPerdata dimaksudkan untuk mencakup pula kerugian yang disebabkan oleh perbuatan yang tidak termasuk tugas yang diberikan pada bawahan, namun ada hubungannya sedemikian rupa dengan tugas bawahan tersebut, sehingga perbuatan tersebut dianggap dilakukan dalam pekerjaan untuk mana bawahan tersebut dianggap dilakukan dalam pekerjaan, untuk mana bawahan tersebut digunakan." 31

\footnotetext{
${ }^{27}$ Ibid., Hlm. 171.

${ }^{28}$ Ibid., Hlm. 17.

${ }^{29}$ Subekti dan R. Tjitrosubidio, Kitab Undang-Undang Hukum Perdata, Jakarta, Pradnya Paramita, 2008, Hlm. 346.

${ }^{30}$ Moegni Djojodirdjo, Perbuatan Melawan Hukum : Tanggung Gugat (aansprakelijkheid) Untuk Kerugian, Yang Disebabkan Karena Perbuatan Melawan Hukum, cet. 1, Jakarta, Pradnya Paramita, 197., Hlm. 128.

${ }^{31}$ Ibid., Hlm. 129-132.
} 
Terdapat beberapa syarat untuk melihat tanggung jawab majikan terhadap perbuatan melawan hukum yang dilakukan bawahan yaitu adanya hubungan subordinasi antara Bank, adanya kesalahan yang dibuat oleh bawahannya tersebut, adanya hubungan antara kesalahan dengan pekerjaan bawahan untuk mana ia dipekerjakan, adanya wewenang atasan dalam kesalahan tersebut, adanya kemungkinan untuk perbuatan melawan hukum itu terjadi meningkat dengan adanya tugas dari majikan, dan kurang hati-hatinya majikan dalam mengangkat bawahannya. ${ }^{32}$

Jadi, terkait dengan bentuk tanggung jawab Perusahaan terhadap tindakan karyawannya adalah, setelah melihat dari sisi hubungan hukumnya. Bentuk tanggung jawab dari perusahaan itu bermuara ke segi perdata yang memberikan ganti rugi baik secara penuh ataupun tidak. Perusahaan dapat bertanggung jawab jika dapat dibuktikan oleh pihak yang dirugikan dengan menghubungkan teori fault on liability dimana beban pembuktian terletak pada pihak ketiga yang mengajukan gugatan agar holding company bertanggung jawab secara pribadi dengan dasar piercing the corporate veil yang harus dapat membuktikan kesalahannya. Dapat disimpulkan bahwasanya segala yang terkait dengan pertanggungjawaban perdata dalam perusahaan yang menugaskan pegawainya dalam meng-handle permasalahan sistem informasi debitur dapat menimbulkan kerugian menurut UU Perseroan Terbatas yang bermuara kepada tanggung jawab ganti rugi setelah diterapkannya piercing the corporate veil terhadap Bank. 33

Ganti rugi yang dibebankan kepada Bank selaku Perusahaan setelah diterapkannya piercing the corporate veil terhadap tindakan hukum pegawainya, ditentukan dari segi prinsip tanggung jawab hukum berdasarkan kesalahan. Ganti rugi yang merupakan ganti rugi Bank terhadap tindakan hukum pegawainya, apabila telah terpenuhi oleh satu prinsip tanggung jawab di atas, maka dapat disimpulkan bahwasanya ganti ruginya merupakan ganti rugi yang terdapat dalam Pasal 1246 KUHPerdata yakni biaya, rugi dan bunga yang oleh si berpiutang boleh dituntut akan penggantiannya, terdirilah pada umumnya atas rugi yang telah dideritanya dan untung yang sedianya harus dapat dinikmatinya. ${ }^{34}$

Khusus ganti rugi karena perbuatan melawan hukum yang dilakukan oleh Bank sebagai atasan harus memenuhi persyaratan-persyaratan yang telah ditentukan oleh di atas agar Bank memberikan ganti rugi terhadap tindakan anak hukum perusahaannya. Jika telah melihat dari segi persyaratan-persyaratan tersebut maka dapatlah dilakukan pembayaran ganti rugi setelah memenuhi syarat-syarat sedemikian rupa. ${ }^{35} \mathrm{Hal}$ ini sesuai dengan kewajiban bagi Bank yang telah dicederai oleh Pegawainya, yakni untuk menciptakan kenyamanan bagi para debiturnya dan menciptakan hubungan yang sehat antara produsen dan konsumennya, sekaligus menciptakan iklim berusaha yang kondusif bagi perkembangan usaha dan perekonomian pada umumnya. Maka undangundang perlindungan konsumen memberikan sejumlah hak dan membebankan sejumlah kewajiban dan larangan kepada pelaku usaha perbankan.

\footnotetext{
${ }^{32}$ Rosa Agustina., Hukum Perikatan (Law of Obligations)., Hlm. 36.

${ }^{33}$ Iwan, Pertanggungjawaban Perusahaan Induk Dalam Perusahaan Group Selaku Pemegang Saham Terhadap Anak Perusahaan Yang Mengalami Kerugian Menurut UU PT, Tesis Magister Universitas Sebelas Maret, Solo, 2014.

${ }^{34}$ Muhammad Syafi'i, Bank Syariah dari Teori Ke Praktik, Jakarta, Gema Insani Press, 2003, Hlm. 134.

${ }^{35}$ Munir Fuady, Perbuatan Melawan Hukum, Bandung, Citra Aditya Bakti, 2005, Hlm. 14.
} 
Argumen tersebut diperkuat dengan Peraturan Otoritas Jasa Keuangan Nomor:01/POJK.07/2013 tentang Perlindungan Konsumen Jasa Keuangan yang dimaksud dengan pelaku usaha jasa keuangan salah satunya yaitu bank, baik itu bank umum maupun bank perkreditan rakyat, baik yang melaksanakan kegiatan usahanya secara konvensional maupun secara syariah, dan konsumen merupakan pihak-pihak yang menempatkan dananya dan/atau memanfaatkan pelayanan yang tersedia di Lembaga Jasa Keuangan antara lain nasabah pada perbankan, pemodal di pasar modal, pemegang polis pada perasuransian, dan peserta dana pensiun pada dana pensiun berdasarkan peraturan perundang-undangan di sektor jasa keuangan. Tidak jarang dalam menjalankan usahanya para pelaku usaha termasuk pelaku usaha jasa keuangan melakukan kesalahan atau kelalaian sehingga menyebabkan kerugian pada konsumennya. Dalam hal ini jelas pelaku usaha jasa keuangan harus bertanggung jawab terhadap kesalahan dan kelalaian tersebut. Pasal 29 Peraturan Otoritas Jasa Keuangan Nomor:01/POJK.07/2013 mengatur jelas bahwa:"Pelaku Usaha Jasa Keuangan wajib bertanggung jawab atas kerugian Konsumen yang timbul akibat kesalahan dan/atau kelalaian, pengurus, pegawai Pelaku Usaha Jasa Keuangan dan/atau pihak ketiga yang bekerja untuk kepentingan Pelaku Usaha Jasa Keuangan".

\section{Kesimpulan}

Dengan adanya kelalaian Bank yang mengakibatkan debitur terkena BI checking, dapat merugikan debitur dan kreditur. Bila melihat adanya hubungan kausal antara perbuatan dengan kerugian apabila dengan menerapkan adequate theorie maka Bank dikatakan melakukan perbuatan melawan hukum yang secara layak dapat diperkirakan akan timbul Dalam Pasal 1365 KUHPerdata, dengan jelas, keharusan adanya hubungan kausal yang timbul karena perbuatan melawan hukum dan dari sekian banyak faktor yang sama-sama menimbulkan akibat, maka hanya dianggap relevan faktor yang memiliki ciri untuk menimbulkan akibat tersebut. Dengan adanya kelalaian dari bank maka menimbulkan kerugian, baik kerugian materiil dan immateriil. Hal tersebut dikuatkan dengan apa yang disampaikan menurut R. Setiawan bahwa perbuatan kelalaian oleh Bank adalah bertentangan dengan kepatutan, karena Perbuatan tersebut sangat merugikan debitur tanpa kepentingan yang layak, yaitu terkena blacklist dari BI checking.

Berdasarkan Pasal 1367 KUHPerdata menggunakan teori tanggung jawab pengganti atau vicarious liability. Bank yang merupakan tempat pegawainya bekerja dibebankan tanggung jawab mutlak (strict liability). Dimana berdasarkan Pasal 1367 ayat (1) KUHPerdata menentukan bahwa seseorang tidak hanya bertanggung jawab untuk kerugian yang disebabkan karena perbuatannya sendiri, tetapi juga terhadap perbuatan orang yang menjadi tanggungannya atau barang-barang yang berada dalam pengawasannya. atau yang biasa disebut. Sehingga terdapat tanggung jawab Bank sebagai atasan terhadap perbuatan melawan hukum yang dilakukan oleh pegawainya, karena telah memenuhi unsur untuk majikan dikatakan ikut bertanggungjawab yaitu adanya hubungan subordinasi antara majikan dan bawahan, adanya kesalahan, adanya hubungan antara kesalahan dengan pekerjaan sebagaimana ia dipekerjakan, adanya kewenangan atasan dalam perbuatan tersebut, dan adanya kemungkinan untuk perbuatan melawan hukum itu terjadi meningkat dengan tugas yang diberikan oleh 
majikan. Hal ini diperkuat dengan Pasal 29 Peraturan Otoritas Jasa Keuangan Nomor: 01/POJK.07/2013, yang menyatakan Pertanggungjawaban Hukum dibebankan terhadap Bank.

\section{Daftar Pustaka / Daftar Referensi}

\section{Buku}

Badrulzaman, Mariam Darus, et.al., (2011), Kompilasi Hukum Perikatan, PT Citra Aditya Bakti, Bandung

Muhammad Syafi'i, Bank Syariah dari Teori Ke Praktik Jakarta: Gema Insani Press, 2003

Munir Fuady, Perbuatan Melawan Hukum, Bandung: Citra Aditya Bakti, 2005

H.R Sardjono dan Frieda Husni Hasbullah, (2003) Bunga Rampai Perbandingan Hukum Perdata, Cet. Kedua IND-HILL-CO

Hermansyah (2011) Hukum Perbankan Nasional Indonesia, cet.6 Kencana Prenada Media Group

N.H.T. Siahaan. (2004), Hukum Lingkungan dan Ekologi Pembangunan Erlangga,

Purwosutjipto, Pengertian Pokok Hukum Dagang Indonesia Jakarta: Djambatan, 2003

Rani Sri Agustina, (2017), Rahasia Bank, Keni Medi

Subekti Dan R. Tjitrosubidio, (2008), Kitab Undang-Undang Hukum Perdata Pradnya Paramita

Widiyono, (2004). Wewenang Dan Tanggung Jawab, Ghalia Indonesia

Zainuddin Ali, (2016), Metode Penelitian Hukum, Sinar Grafika

\section{Jurnal}

Ronny Prasetya, Pembobolan ATM, Tinjauan Hukum Perlindungan Nasabah, Lex Crimen, Vol.II/No.1/Jan-Mrt/2013.

Mauritz Pray Takasenseran, "Perjanjian Antara Bank dengan Nasabah Menurut Undang-Undang Nomor 10 Tahun 1998", Lex et Societatis, Vol.IV/No.7/Juli 2016.

Selamat Widodo, Tanggung Jawab Perdata Bank Terhadap Tindakan Fraud Karyawan Yang Merugikan Nasabah, Kosmik Hukum, Vol 14, No 2 (2014), DOI: 10.30595/kosmikhukum.v14i2.742 
Anggita Maynanda Pratiwi, Perlindungan Hukum Terhadap Nasabah Debitur yang Terlapor Dalam Sistem Informasi, Diponegoro Law Review, Vol. 5 No. 2, 2016

Andi Nova Bukit, Pertanggungjawaban Bank Terhadap Hak Nasabah Yang Dirugikan Dalam Pembobolan Rekening Nasabah (Studi Di Pt. Bank Rakyat Indonesia Tbk, Kantor Cabang Medan Gatot Subroto), Jurnal Ius Constituendum, Volume 4 Nomor 2 Oktober 2019

Latumena, Pieter E, (2017) “Reposisi Pemberian Kuasa dalam Konsep Volmacht dan Lastgeving Berdasarkan Cita Hukum Pancasila", Hukum dan Pembangunan 47 (September 2016 - Maret 2017)

Rini Dameria, Achmad Busro, Dewi Hendrawati, (2017) “Perbuatan Melawan Hukum Dalam Tindakan Medis Dan Penyelesaiannya Di Mahkamah Agung (Studi Kasus Perkara Putusan Mahkamah Agung Nomor 352/Pk/Pdt/2010)" Diponegoro Law Journal Volume 6, Nomor 1, Tahun 2017,

Busro, Achmad, (2012)., Hukum Perikatan Berdasar Buku III KUH Perdata, Percetakan Pohon Cahaya

Moh. Zainol Arief dan Sutrisni (2014), Perbuatan Melawan Hukum Dalam Transaksi Jual-Beli Melalui Internet Ditinjau Dari Buku III Kuhperdata", Jurnal Jendela Hukum fakultas Hukum Unija. Volume I Nomor 2 September

Rivo Krisna Winastri, Ery Agus Priyono, Dewi Hendrawati, (2017). “Tinjauan Normatif Terhadap Ganti Rugi Dalam Perkara Perbuatan Melawan Hukum Yang Menimbulkan Kerugian Immateriil (Studi Kasus Putusan Pengadilan Negeri Istimewa Jakarta No. 568/1968.G), Diponegoro Law Journal Volume 6, Nomor 2

Moegni Djojodirdjo, Perbuatan Melawan Hukum : Tanggung Gugat (aansprakelijkheid) Untuk Kerugian, Yang Disebabkan Karena Perbuatan Melawan Hukum, cet. 1 Jakarta: Pradnya Paramita, 1979

Iwan, "Pertanggungjawaban Perusahaan Induk Dalam Perusahaan Group SelakuPemegang Saham Terhadap Anak Perusahaan Yang Mengalami Kerugian Menurut UU PT",Tesis Magister Universitas Sebelas Maret, Solo, 2014. 